\title{
The Revolution of 1908 in Turkey
}

Leiden: Brill. pp. 341+xii. ISBN: 90-04-10791-6 (HB).

This is a book version of Kansu's doctoral thesis, in which his objective "was to show [the political] transformation [in the beginning of the century]-however elusive- by re-telling the political history of modem Turkey in a radically different fashion" (p. ix). He states that this radical approach is based on an "historical' viewpoint [which is] opposed to a "political' one"(p. ix).

In order to show his radical re-telling of the political transformation of the Ottoman Empire in the beginning of the previous century, the book commences with a critical but analytical and enjoyable chapter on Turkish historiography by making special emphasis on the interpretation of the Revolution of 1908 . In doing so, Kansu summarises the attitudes of the Turkish academics and intellectuals towards the interpretation of recent Turkish history. This in turn is an attempt to clarify his ideological stand as regards the Kemalist revolution of 1923 and the Young Turks.

The first concept the reader encounters with the first chapter is 'Revolution'. For Kansu the year 1908 is the most crucial year in modern Turkish history, "because a new era opens before the Turkish social formation through a genuine revolutionary movement. 1908 is the beginning of the establishment -for the first time in modern Turkish history- a constitutional monarchical form of government which legitimates itself on the presence of a representative parliament to which it is totally responsible" (p.1). It has to be stated that while the "genuine revolutionary character" of the constitutional movement is open to question, Ottomans had the first parliamentary political structure not in 1908 but in 1876, albeit it lived only a short while due to Abdulhamid II's political ambitions and, one has to accept, it was not as strong as the 1908 experience in its representation. However, Kansu claims that it was the 
first of its kind in the Ottoman Empire, as the aim of the previous experience "was nothing more than a re-arrangement and re-establishment of the prerogatives of the absolutist monarchy as well as the monarch's position vis-vis the bureaucracy" (p. 2).

So as to demonstrate the 'genuine revolutionary' character of the 1908 Constitutional Movement and of the Committee for Union and Progress (CUP), Kansu criticises the approaches taken by Turkish historiography for degrading and neglecting the 1908 revolution and giving primacy to the Kemalist Revolution of 1923 . Thus, the central thesis of this book is to show that the real revolution was the 1908 movement, as for Kansu the formation of the Turkish Republic is "mistakenly identified as a revolution" but in the real sense, it was a "coup d'etat" (p. 5). This firm but accurate criticism serves the ideological inclination of the author in his attempt to give primacy to the 1908 Movement, which in the real sense was the predecessor of the Kemalist revolution. He manifests his radical approach in dealing with the Kemalist political discourse, and bravely enough he calls the new regime of the Turkish Republic a "Kemalist dictatorship" (p.12). Such a real radical approach is not common at all among the Turkish intelligentsia and the academia; therefore, Kansu deserves a boost to his radical approach as he critically and openly attacks official Turkish historiography.

In the chapter, Kansu critically examines various versions and approaches of Turkish historiography as regards the breaking point in Turkish history. These are mainly continuity and discontinuity theses and modernisation and dependency theory and their variants. He rightly observes that due to "personality worshipping" or "hero-worshipping" in the leadership of the "cult symbol" of Ataturk (p. 12), all these approaches and versions, regardless of how radical they might be, in the end submit to the Kemalist paradigm, because "the elements of Kemalist ideology firmly stay in place, providing the general framework as well as the boundaries of historical research. In short, the paradigms of Kemalist ideology help shape almost each and every study no matter what the approach of the researcher may be"(p. 4). This firm statement explains the lack of original and genuine academic work among Turkish academics.

Due to the constraints imposed by the Kemalist paradigm, academics and intellectuals, whichever theory they use, accept the "First World War and the so-called 'War of Independence' as a legitimate breaking point for Turkish history" (p.4). Kansu rejects this discontinuity thesis, as well as 
modernization theory which emphasis 1923 as a point when the real modernization began. He further criticises the dependency theory and its versions for failing to acknowledge the internal dynamics of the change that was taking place in the Ottoman and/or Turkish society.

For Kansu, the reason for all these justified criticisms and rejections of the Turkish historiographers is the fact that they ignore the 1908 and give primacy to 1923. In other words, he criticises all those variants and approaches because they fail to support his own ideological conviction that 1908 Movement was the breaking point in Turkish history, which, according to Kansu, was not "change from above" but had real popular support. Thus, he produces his own interpretation to justify his ideological position. If the conventional historiography fails because of its support to the so-called Kemalist Revolution, his defence of CUP or the Young Turks and his argument that 1908 represented "a revolution from below" is another case of fallacy and elitism. Those who are well aware of the policies pursued by the CUP during its reign in power, which are not covered in this book, will agree with this. In contrast to Kansu's claim of having 1908 as the breaking point in Turkish history within the continuity theory, one has to go beyond to understand that both the 1908 and 1923 Movements were the products of ongoing westernization attempts initiated by the Ottoman Sultans as far back as the 17th century. Despite all these, Kansu succeeded in disclosing the true nature of Turkish academics, and hence achieved his aim of "criticis[ing] the conventional approaches in writing modern Turkish history" (p. 25), albeit the result might serve for his own ideological stand.

Kansu justifies the year 1908 as being a breaking point through the changes which took place in society, politics and economics. It is true that in terms of institutions, there was a break, but in terms of real politics, there was hardly any change. Even without any hesitation, it can be expounded that CUP policies were harsher than those of the monarchists. Take as examples, their ethnic politics and domestic affairs as well as the foreign policies, which did not have a clear objective and hence brought the empire to collapse. This was an eventual and inevitable consequence which was delayed by the establishment until the Young Turk administration.

After clearly identifying his objective of the book being an attempt to prove that the 1908 Movement was indeed a 'revolution' but was not a 'change from above', the second chapter attempts to provide evidence for such assertions by describing the prevailing popular unrest in various parts 
of the Empire. For Kansu, the unrest is quite important as the "events of this period involved such profound social, political and economic changes that it has to be considered as nothing less than a revolution" (p. 29).

The chapter lucidly in very much detail describes the unrest, the reasons for unrest and the people who played a role in the organizations of them. As the title of the chapter (tax revolts) suggests, the prevailing unrest had been caused by the ever-increasing tax burden and newly levied taxes on every sector of the society from "peasants in the villages, artisans and shopkeepers in the town and merchants in the cities" (p. 31). The unjust tax collection system only helped to aggravate the burden of the taxpayers.

As the chronological account presented by Kansu demonstrates, 'civil disobedience' began in Kastamonu in January 1906 after the imposition of new taxes, and spread to other cities of the Empire but mainly took place in Anatolian towns and cities. Kansu contests that "by early 1908, various forms of civil disobedience had become commonplace in almost any town, not only in Anatolia proper and Macedonia but also in areas which were considered to be at the fringes of the Empire" (p. 71).

To justify his claim, Kansu argues that the intention of unrest was not limited to rejecting the tax burden, but, for example, "the October Revolt at Erzurum had grown from a revolt against unjust taxation without representation to an outright and widespread rejection of the existing regime"(p.47). He further argues that the mentioned unrest was due to the activities of CUP, which was strengthened by the support rendered by local populations. Kansu unceasingly repeats this to convince the readers in a non-academic manner about the popularity of CUP. However, unrest began as a revolt against the tax burden, and he states in various stages of the chapter that they were mainly organized and carried out by local notables, sheiks, local landowners, merchants and religious elite or the ulama. In contrast to Kansu's conviction, the objectives of the local elites were not to be against the regime, but to voice the difficulties they were facing. Thus, the author's argument that CUP coordinated all the demonstrations in the form of tax revolts and that the real objective of people was to oppose the regime (p. 31) is rather a wishful reading of the events took place in the pre1908 period. In any way, as can be seen between the lines, CUP did not exist in the Anatolian cities at all, but it did attempt to use this unrest towards its own ends, which is evident from Kansu's statement that "the revolutionaries us[ed] the unpopularity of the new taxes as their rallying point" (p. 48). 
Kansu uses the army's reluctance in deterring the unrest to justify his position that CUP's revolutionary position influenced the army. This cannot be read as the army's support to the unrest or CUP, but rather, as acknowledged by Kansu, as an attempt to strength their own position against the administration to force the treasury to pay the salaries, which had been terribly in arrears, and to get increases. Thus, the army had its own hidden agenda rather than voluntarily giving support to the call of CUP.

It seems from the account of the events just before the proclamation of the Constitution that CUP enjoyed rather good relations with the ethnic groups including Kurds, Lazes, Armenians, Arabs, Macedonians and Albanians. As the chapter explores, it had support, at least in the initial period, from these ethnic groups. Not only this, but it seems that it was organized among these ethnicities long before it was in the ethnic Turkish cities. However, during its governance, CUP pursued very harsh policies against other ethnicities such as the Armenians. By following the discussion in the first chapter, this reminds us that it is true that there is a continuity in Turkish historiography, and that continuity is that the Kemalist regime adopted the same policies as its predecessor, CUP. As far as the public policies are concerned, these two movements are not two different things, but the same understanding led by different people who had personality clashes with each other.

Chapter 2 provides valuable insight into the nature of society in the Ottoman Empire as well. For instance, through out this chapter, Kansu presents how people (inclusing women), organized protests and were involved in demonstrations, which could end in the sacking or transferring of the governor of that city. Again, he mentions that people protested against the rise in the price of flour and bread, and immediately Council Ministers lowered the price (p.77). This should be read as the demonstration of the 'civil society' nature of the Empire. Thinking about present Turkey with its so-called modern and democratic regime, one cannot see a case that the government sacked a high-ranking government officer by bending to the demand of the society. While even the despotic regime of Abdulhamid II had to listen to the people, then what name could be given to the nature of the modern Turkish regime, which never intends to act according to the preferences of people by whose will they are elected? Therefore, it is very normal that the Palace "interpreted [the unrest] as being unique in Turkish history" (p. 48), as such interest is still unthinkable in present-day Turkey. 
After using tax revolts to display the so-called public support for CUP, Kansu presents "the events that eventually led to the Revolution" in chapter three. In other words, the previous chapter is allocated mainly to the role of the public, while in the third chapter the focus shifts to the role of the army to show the further popularity of the Revolution by the participation of the "rank and file of the military" (p. 73). Despite the major role played by the military, in order to preclude the role played by the elites, Kansu insists that "it was the civilian aspect of the uprising that gave the movement its revolutionary character" (p. 74). Yet, he cannot help himself from disclosing the military character of the Revolution, i.e. revolution being change from above, by accepting that "more critical than civil disobedience, however, was military unrest" (p. 81).

Kansu's claim that the civil unrest was the main factor in bringing down the 'ancient regime' is undermined in this chapter, in which the activities of the army towards the destruction of the old regime is presented. It is obvious from the presented information and events in this chapter that the military obsession to change the government was the main cause of the Revolution. Because, if it had not been the case and if the civil disobedience had been the determining factor, then in those cities where the major civil outbreaks took place, one would expect to see the military participation as well. However, we do not hear of any politically motivated military disturbance there; instead Kanus concentrates on the military unrest in Macedonia and the Balkan cities of the Empire. This is obvious from the declaration of the Revolution, which was declared on 23 July 1908 in the Balkan cities of Monastir and then in Salonica. In other words, the revolution was not declared in the cities such as Erzurum, Van or Bitlis where the major civil outbreaks in terms of tax revolts took place. Had it been the case, then Kansu could be appropriate to claim the civil nature of the Revolution. On the contrary, it was declared in the cities where the army was disturbed and rose up. Contrary to the claim of the author, this clearly indicates the military nature of the revolution.

Proclamation of the Constitution was made on July 241908 by the Sultan, who "ordered the convocation and election of Parliament in accordance with the Constitution" (p. 101). Kansu presents the events such as celebrations, which followed the proclamation. The celebrations apparently took place in thousands, in Istanbul a hundred thousand, in the major cities of the Empire. He uses these public celebrations to insist that the revolution was brought about by the public, when he argues that 
"public expression of extreme joy ... confirms once again the popular aspect of the Revolution" (p. 113). However, celebrations cannot be good evidence for proving the civil nature of the revolution, as to do that one has to show that the public was involved in the process of bringing about change; celebrations can only be interpreted as the public's pleasure with the end result.

Chapter 4 is on the establishment of the parliamentary system in the Ottoman Empire, and hence, chronologically describes the events and changes which took place in the state apparatus, in particular in the civil and military bureaucracy. Kansu states that "the state apparatus was totally disrupted immediately after the revolution" (p. 115), and CUP played an important role in a "clean sweep" in the "civilian and military bureaucracy". For him, disrupting the bureaucracy is another indication that it was a revolution.

Kansu mentions that with the Imperial Decree of August 1, the Sultan granted the Constitution and the convocation of the Parliament. Although he does not mention it, this received a huge welcome from the Islamic sector of the society as well, because it meant an end to the despotic regime of Abdulhamid II, as it declared the end of the spies system, which had disrupted so many lives of people across the political spectrum of the time. It granted rights such as the equality of all citizens, the right of free travel, the right to free education, the right to fair trial, the right to free assembly and the abolishment of press censorship (p. 120). These are indeed crucial changes, which are strong enough to convince one to join the author in his conviction that 1908 brought a halt to the 'old regime'. However, trying to demonstrate that these were the values that CUP held, as Kansu does, would not serve justice, as one has to analyse the post 1908 period to see the real politics and, thus, the despotism of CUP as well.

In the later part of the chapter, Kansu presents information about the formation of cabinets, their members and the program of the government. Among many issues from the program of the government desired by CUP, creation of a "uniform national education program" is rather important, as this was a clear indication of CUP's disregard to the different needs of various religious and ethnic groups within the Empire. This issue for the author, indeed, is a matter of modern development, without considering its ultimate outcome on the peace of the society. Another indication of the CUP's authoritarian attitude was CUP's assistance to the authorities in taking the organizers of a strike into custody, which Kansu passed by 
without any comments. For a movement to act in such a way after supporting the unrest should have told something about their prospective policies to the people of the time.

While Kansu criticizes the old regime for its 'corruption' and partisan policies, and repeatedly praises the new regime for curbing these, he recorded statements which contradict his conviction. For instance, he states that the new government faced the issue of reducing the number of corps, "a task which would be made more difficult by the fact that a large majority of the younger officers were supporters of the CUP" (p. 154). This lucidly indicates the partisan politics of CUP.

Kansu concludes the chapter by arguing that restoration of the 1876 Constitution substantiated the support for as well as the organization of, CUP; thus he claims that it had been expected that CUP would win the election with a landslide victory (p.156), a statement that needs to be verified by the election results.

Chapter 5 is on the opposition to the new regime, and commences by criticizing the political discourse of the 'old regime' and CUP's proposed ideas about the new political structure. Kansu criticizes the old regime because it did not impose a 'centralised' rule and ties on various ethnic and religious communities which constituted the Empire. In that "non-modern political entity", the author criticizes that different "communities had been held together through a loose state structure where communities had a large degree of autonomy" (p. 157). This is evidence of why Kansu is terribly critical of Prince Sabahaddin, the leader of the Liberal Union (LU), as Kansu supports CUP's position of a centralized system and mentions that CUP was "determined to destroy" the existed structure (p.157). The changes for the administrative structure included "a new concept of state, along with a new concept of citizenship" (p. 157). This "conception of citizenship could not tolerate the separate classification of citizens into hierarchical categories of race, religion or ethnic identity" (p. 158). Despite all his conviction about CUP's policies on this matter, Kansu acknowledges the fact that this new citizenship "stripped individuals of their old local and parochial identities" (p. 159), as in the civil society oriented, decentralized, Ottoman system, "state authority was neither superior nor exclusive" (p. 158). Although he supports ending the decentralised administrative system and praises the centralised system, the so-called modern changes brought an end to the harmony between all those various communities defined on religious and ethnic lines. 
Educational reform as included in CUP's election manifesto became a disputed issue, as the ethnic groups under the old regime were free to establish their own system, while CUP was proposing uniform educational system and was envisaging "impos[ing] Turkish as the language of instruction in all secondary schools" (p. 160). Later CUP went further to make Turkish even obligatory in the primary schools, and according to the election program of CUP, "all schools would be under the state supervision" (p. 163). This increased the tension among other ethnicities.

Against the centralised attempt of the CUP program, various ethnic groups "advocated a wide measure of decentralization and autonomy" (p. 161) which was propagated by Prince Sabahaddin. For instance, the Armenian Revolutionary Federation (ARF) "opposed a system of centralized administration... [and] favored the widest degree of local, legislative and administrative autonomy" (p. 168). This was the beginning of the deterioration of the relationship between CUP and ARF, although they collaborated with CUP in bringing down the old regime. Such obstinate political attitudes of CUP brought about opposition from minority groups. This is evident in the statement where Kansu openly states that "the Greek community was the Unionists' ablest and best organised opponent" (p. 172). It is due to such tension that minority groups, such as Greeks and Albanians, became sympathetic to Prince Sabahaddin's LU, despite the fact that they decided "not to formally ally themselves with the LU" (p. 191). This is evident when the author contends that "the Albanian nationalists seemed to favour the program of decentralization which Prince Sabahaddin had advanced" (p. 179), and the Macedonians and the Greeks "placed great hopes in Prince Sabahaddin" (p.186).

According to Kansu the establishment of the LU, which succeeded the Society for Decentralization and Private Initiative, by Prince Sabahaddin on the ground of promoting "a system of decentralized government with regard to the ethnically or religiously divided provinces united all the opposing ethnic and religious groups against CUP" (p. 184). This provides an opportunity for the author to exert his biased ideological conviction in favour of CUP by labelling Prince Sabahaddin and his group as 'monarchist' and including them among the 'reactionary' groups despite the record of earlier talk prior to the Revolution between CUP and LU for fusion (p. 184). A decentralized political structure could have been the best way to ease the tension between the state and its various ethnic and religious subjects, which plague modern Turkey as well due to its centralized 
authoritarian nature. However, the author, being a CUP partisan and nonpluralist, as it seems from his remarks despite his criticism of the Kemalism and Kemalist academics, and despite his liberal ideological conviction favors centralzsed political structure and believes that Prince Sabahaddin's proposals were nothing more than a plea for the continuation of the system which existed under the old regime, and his ideas were totally counterrevolutionary" (p. 188).

As regards Prince Sabahaddin, Kansu asserts his ideological choice by siding with and praising the political conservatism of CUP and opposing pluralist liberalism by degrading Prince Sabahaddin as a 'monarchist'. In a non-academic manner, he persistently repeats this. It is an undeniable fact that Prince Sabahaddin was part of the royal family, but this certainly does not mean that he was a "monarchist". On the contrary, he should be regarded as the founder of liberal political thinking in Ottoman Turkey. Against the centralized and authoritarian administrative regime of the CUP - which cost the Empire even the loss of its Muslim Ummah altogether, let alone non-Muslim nations of the Empire -Prince Sabahaddin and his party favored and propagated 'decentralization' to enable each ethnic group to participate to the administration of its locality. The decentralized administration system was part of his westernisation thoughts. As this implies, he supported westernisation as CUP did, but his version supported the development of "individualism" against communitarianism in the progress towards westernization.

The Prince's thoughts and policy alternatives should be perceived as the beginning of "participatory" politics in the Turkish intellectual tradition, albeit it never found an opportunity to be pursued in the governance. However, CUP fiercely attacked his ideas of decentralization on the grounds that it would shake the foundation and unitary feature of the empire, which terribly resembles to the prevailing attitude of the Turkish civil and military elite against the ethnic demands. Knowing Prince Sabahaddin's liberal ideas and his party's liberal policy alternatives, the author surely did not do justice by repeatedly mentioning him as "monarchist". It has to be put on the record that author himself does acknowledge that Prince Sabahaddin was in exile before the eruptions which lead to the 1908 revolution, and that he opposed the Hamidian regime and in February 1907 he "distributed a seditious proclamation in Istanbul" (p. 76) against the regime. Despite the Prince's anti-regime activities, apparently his contribution to the Revolution is qualified by Kansu, as he had opposing views to those of the CUP's. 
It should be recorded that Kansu has cursory and inconsistent allegations about the Prince. For instance, he alleges that the Prince was after a coup d'etat for capturing power, and CUP disapproved of this on the ground that it is was against "genuine revolution" (p.79). However, this allegation contradicts with the claim that CUP was, at some point, "confident that they should and could destroy the established regime through armed resistance and bloodshed if necessary" (p. 71). Hence, if CUP had such intensions, then there is no reason why it should criticize the Prince for such thoughts, if ever he had such a hidden agenda. On the other hand, if he envisages, as alleged by the author, taking over the government by a coup d'etat, then the author's blame that he was a monarchist does not make much sense.

Overall, this is an important matter, as this issue reflects on the modern Turkish political system as well. Because, while the CUP tradition was and has been carried out by the republican and secular military and civil elite conservatives and their political parties, Prince Sabahaddin's position has always found an audience among liberal intellectuals and politicians, though their numbers have not been enough to change the political structure of so-called modern Turkey.

In sum, as acknowledged by Kansu, those people who were affected by the mentioned changes potentially became part of the "reactionary forces" (p. 159). His persistent statement that CUP had popular support seems not to have much substantiation, as he himself points out that "the struggle between CUP ... and the ethnic, national, and religious forces ... began with the ... establishment of the new [regime]" (p. 159). CUP's obstinate centralized, and hence authoritarian policies eventually took its toll when such policies forced different ethnic communities including Albanians, Greeks, Armenians and Arabs to work for their own national ends and liberations. This meant, as inevitably accepted by Kansu as well, that "the Unionists' goal of dividing the political field between liberalism and conservatism, transcending ethnic and national boundaries, was therefore defeated" (p. 182). As a result, the whole society became opponents of CUP except ethnic Turks in better provinces of the Empire and mainly the Jews, albeit being a small minority group.

Chapter 6 is about the elections and events that led to the elections as well as the presentation of elections results. It was not easy to complete the election without problems but, as Kansu states, elections began in October 1908 and were completed before the opening of the Parliament in November. 
In contrast to Kansu's conviction, it seems that CUP was not that liberal after all, he ostensibly acknowledges this when he reveals that "as elsewhere, the [CUP] was anxious to prevent the election of outright reactionaries in Aleppo. Accordingly, it had instructed the Governor of Aleppo to eliminate reactionary and monarchist candidates from the elections" (p. 233). This implies that CUP meddled with elections.

Kansu provided a detailed account of the election results, and these can be employed to test the firm claims made by Kansu regarding the popularity of and mass support extended to CUP. Election results were broken down according to constituencies, with detailed information about deputies, including the party they were elected for and any change in their political affiliations. Kansu's detailed information reveals that in total 281 deputies were elected all over the Ottoman Empire. Out of these, only 67 of them elected and/or remained as CUP members during their tenure in the office. However, Kansu states that only 54 of them were committed CUP members (p. 238). The discrepancy between Kansu's statement and the list is because deputies changed their political affiliations. In any case, 67 deputies in total or 54 committed CUP members out of 281 clearly indicates that CUP did not have popular support, as this merely corresponds to about twenty percent, which falls very short of majority. Despite this, the author carries on with his wishful thinking and states that CUP "had carried many districts in the elections and appeared certain to dominate the Chamber" (p. 237). The election results entirely nullify this statement, and therefore, he corrects this in the following page by stating that, "since this figure constitutes a minority in the Chamber, we can easily dismiss allegations that the Chamber was overwhelmingly Unionist" (p. 238). Thus, CUP could not get popular support in the elections.

It is worthwhile to enunciate the ethnic backgrounds of the elected CUP deputies as this would help to test Kansu's claim that the CUP was popularly supported across the population. From the detailed election results presented by the author, it can be inferred that among these 67 deputies, 51 were ethnic Turk (or 44 out of 54). This means that a very large percentage of CUP deputies were ethnic Turk; this is acknowledged by the author when he states that, "by the time the elections began, it had become apparent that the Unionists could count on the overwhelming support of the Turkish electorate..."(p. 191). This, thus, invalidates Kansu's claim that CUP enjoyed cross-ethnic support. Accordingly, among 67 CUP deputies, there were only two Albanians, three Jews, four Armenians, one Greek, 
five Arabs and one Kurd. Although Kansu refrains from providing clear reasons for this, perhaps for ideological reasons, it is probably true that other ethnic groups forecasted the possible future of a possible CUP government under which their destiny as not being Turk would not have been a happy one; the Arabs, Kurds and Armenians were the major victims of CUP's chauvinistic and nationalistic policies despite its initial positive, but not genuine, approach to other ethnicities. As Kansu acknowledges, it seems that for non-Turkish ethnic groups "the new regime meant hopes for autonomy, and nationalist candidates ran against Unionists" (p. 221).

From the presented election results, it is possible to find out the constituencies of the elected CUP members as well. They were mostly elected from Turkish-dominated districts of the Empire: Western and Eastern Thrace, Western and Central Anatolia, and of course the majority were from the Anatolian districts. Since Kansu claims that CUP was involved in the tax revolts and supported by the people of the districts where the tax revolts took place, analyzing the constituencies of CUP deputies can provide evidence for that. He presents the cities/districts, among which are: Erzurum, Trabzon, Bitlis, Van, Izmir, Bursa, Monastir, Kastamonu, Sivas, Samsun, Diyarbekir, Aleppo, Damascus and Mosul. CUP could not get any of its candidates elected in Erzurum, Trabzon, Bitlis, Van, Monastir, Sivas, Diyarbekir, Damascus and Mosul. Among the cities where revolts took place only, in Izmir (3 deputies out of 6), Bursa (1 out of 4), Kastamonu (4 out of 4), Samsun (1 out of 4) and Aleppo (2 out of 7), the CUP had limited success. Consequently, the result of this analysis resplendently indicates that CUP was not strong after all in the revolt-torn cities of the Empire. In addition, results contradict Kansu's argument that "CUP had extensive networks in Macedonia and Anatolia, especially Erzurum, Bitlis, Van and Trabzon" (p.68-69). This is far from being validated. Kansu justifies this by arguing that CUP was "strong in cities and towns which were economically advanced" (p.212). This, unfortunately, indicates the elitism of CUP despite Kansu's criticism of the elitist approach of the Kemalists of modern Turkish history.

In summary, the analysis of election results sheds a great deal of light on our understanding of the so-called popularity of CUP among the masses. However, to avoid backing off from his convictions, Kansu did not attempt to analyse the election results in full detail.

Lastly, this book is published by Brill, which is very well known for its 
quality printing. However, there are a number of grammatical and spelling mistakes. Among these, the following are instances: p. 191, "LU was from the very start, was crippled", repetition of "was"; p. 238, "opposition on certain issues that the put", 'the' before 'put' should not be there.

Kansu, being a liberal historian, consistently and appropriately dislikes the conventional and official attitude of the modern Turkish historians, and throughout the book rejects the views of the establishment on the Revolution of 1908. In the book, he offers his own interpretation that justifies his own pre-conceived ideological stance that the "revolution was not changed from above" and, thus, CUP had the full support of the public. However, in doing so, like the historians he criticises, he falls into the same trap of partisan biases and forces his reading of history into an interpretation that defends CUP. As has been shown, CUP did not have formidable public support. It should be recorded that the repetition of strong statements in favor of his ideological choice does not very well suit the seriousness of an academic study.

In terms of the sources used to assemble data as well as information, the author mostly relied on secondary data, such as books, articles, newspapers and journals. It happens that he refers to the same sources subsequently and very often, which must be due to the lack of primary data, as there is no indication that archives were consulted in assembling primary data.

A minor but symbolic point is that Kansu did not use the abbreviation for Committee of Union and Progress (CUP), and hence repeated the long name continuously in the original form. This reflects his firm ideological feeling, as it seems that he did not like to 'desacralise' an entity that he adores. This is evident throughout the book as he imbued it with repeated personal conviction about CUP.

Despite all the shortcomings, his is a novel attempt to uncover the historical dust over CUP, or the Young Turks. As being an analytical and critical study in political history and historical sociology, I would recommend it to those historians, sociologists and political scientists who research political transformations and their sociological and political roots, as well as to the researchers on Ottoman an Turkish studies.

Mehmet Asutay Leicester University 